I University of Oregon, Department of Sociology, Eugene,

OR, United States of America

mnorton@uoregon.edu

https://orcid.org/o0oo-000I-59I8-0I39

Matthew Norton'

\title{
THE RELATIVE AUTONOMY OF JEFFREY ALEXANDER
}

Whatever one's stance on the strong program in cultural sociology, it is indubitably distinctive, and possibly strange: a self-consciously programmatic theoretical and empirical paradigm that is a going concern in US sociology in the twenty-teens. That puts it out of step with some of the most powerful intellectual streams in contemporary US sociology in which theory tends to play a more restrained, supporting role. It is this relative autonomy of the strong program in cultural sociology from the mainstream of American sociology that I want to focus on in this reflection on Jeffrey Alexander as a teacher and mentor. For it is in his role as the architect and principal engineer of a relatively autonomous intellectual program and institutional setting in a time when such spaces are not in vogue that he exerted his greatest and longest-lasting influence on myself and many others.

As important as it now seems to my own professional intellectual formation, throughout my time as Jeff's student I took it entirely for granted: an apprentice turned loose in a shop already strewn with powerful tools and excellent teachers, the rent paid, the materials to hand, and entirely unaware that the shop, the tools, and the community that brought life and purpose to it all had to be built before they could be so freely used, happily oblivious to the fact that program building, bringing an autonomous theoretical tradition into being, consists far more of the "strong and slow boring of hard boards" that Weber (I958: I 28) claimed for politics than the simpler flash of a pretty argument, a 
big book, or a widely-cited article. My purpose in this essay will be to touch on two main elements of this assiduously made relative autonomy of the strong program: its theoretical foundations and motivations, and its institutional forms. For in thinking about Jeff as a teacher and a mentor, the specifics of what we in the strong program were and are doing and trying to do, learning and trying to learn, only seem to find their proper significance when they are accounted for as facts in the making.

I must now admit that I was (in some respects!) a poor student of my teacher. I read, knew, and found provocative and engaging Jeff's then current work, as well as earlier work that had come to be central strong program source material. I also knew that he had some kind of past theoretical connection with Parsons and neo-functionalism. It wasn't until my final year as a graduate student that I realized I might be missing something from the massive four volume work that launched Jeff's career. I was; I've done the reading now. But from the perspective of the strong program's analytical autonomy perhaps the most important point about the Theoretical Logic in Sociology series is its conviction about the deep significance of theory for sociology at a time when the discipline was falling in ever-deepening love with the middle range. And that theory-forward stance, reflected in its theoretical lineage, I think, is central to the relative autonomy of the strong program. Here's one way that Jeff has articulated his and the strong program's relationship to theory that gets at this idea. It's a long quote, and I think a revealing one:

Sociologists envy and imitate the extraordinary lucidity and realism of the hard sciences. Perhaps, if we work hard enough, we can match their ability to mirror the structure of the world. So in qualitative work we talk 'observational' methods, worry about converting impressions into field notes and generating grounded theory. In quantitative work, we diligently convert social qualities into countable things, to ensure our indicators have statistical validity and to separate spurious correlation from robust causality.

I would by no means gainsay such efforts, but I would challenge the world view of realism to which they are typically attached. An obsessive concern with observation, induction, and reflection makes us blind to the role that moral and intellectual imagination plays in generating important sociological findings. And not just in generating findings, but in feeling and believing them to be true.

I am pointing here to the independent role of theory, to how it comes before observation and interpretation. Strictly speaking, we do not observe actions, make records of events, or compile data about social structures. What we do is to make interpretations of actions, events, and structures in light of our theories, our presuppositions about how people act, what events are like, how social structures feel and which are most relevant.

If we say we are interpreting, then sociology is not a reflection of reality but a construction of it - in light of theory. What we are actually doing as sociologists is making meaning. Observations provide us with ways to exemplify, specify, and revise general theoretical types. Empirical phenomena provide new notes 
that we play on familiar chords; sometimes they provide new chords we play in a familiar key; only on the rarest of occasions do they lead us to play in a different key (Alexander, 2011: 87-88).

The strong program isn't a general social theory, described by Merton as "all-inclusive systematic efforts to develop a unified theory that will explain all the observed uniformities of social behavior, social organization, and social change" (Merton, I949: 39). But that general-theory ancestry that I spent my graduate career largely ignoring is, I think, central to the autonomy of the program. The middle-range malaise is that it all-too-easily settles into an incessant rearranging of the furniture, always suited to the occasion but ultimately without a point of view. Some might argue that theory ought not provide the point of view. That's an important question. But theory certainly can provide one, even if not as general and encompassing as the antinomies and syntheses arrayed in Theoretical Logic, and what one sees from a theory-driven viewpoint may well differ in usefully generative ways.

One of the things that makes the strong program in cultural sociology a program is its claim to an intellectual ground somewhere between the mercenary middle-range and true-believing paladins of this or that general theory. Its theoretical claims to the way that meaning matters and the ways that it can, should, and should not be analyzed, are not limited to any specific swath of social life. Indeed, perhaps the main point of the strong program is that the causal significance of culture, even though now widely recognized, is still underestimated and often misunderstood. It's not a general theory, but it is an adventurous one, inviting efforts to bring its cultural sociological approach to questions and topics where culture's significance can be further teased out and analyzed, including in areas of inquiry where the salience of meaning is already well-known. And this autonomy of inquiry comes from Jeff and his fellow traveler's efforts to spin the strong program from the source material of sociology's general-theory traditions and the broader conviction that to do sociology is always to do theory. It can still speak to the middle-range, but it comes from elsewhere, and behaves accordingly. "When in Rome do as you done in Milledgeville" (to quote Geertz (2000: 72) quoting O'Connor), it turns out, is a good motto for relatively autonomous theory.

What this theoretical inheritance looks like in practice is a strong commitment by most in the strong program constellation to the centrality of theory in the conceptualization and conduct of empirical inquiry. This effort to pursue a set of concepts, mechanisms, arrangements, functions, and causes across a wide swath of empirical topics poses difficulties - e.g. consistency vs. innovation; how much does and should the theoretical influence the empirical focus - but it also provides a resource that enables some autonomy from the way that others approach similar questions. The strong program provides an alternative ground of questions, concerns, and analytical strategies and tech- 
niques for pursuing sociological questions and constructing sociological explanations, a different line of sight. In my experience this kind of autonomy is especially valuable for graduate students because it can help to provide new angles on long-standing or newly popular questions - exactly contrary to the knock that intellectual programs narrow the range of thought. A program of this sort need not be approached dogmatically to provide a different vantage point from which to challenge, enrich, or otherwise engage with contemporary sociological debates and questions. This is only possible, though, because, on the one hand, the strong program has its roots in general theory, but, on the other, it has abjured being a general theory that may have trouble talking to any but its own partisans, in favor of becoming a theoretical perspective that is relatively autonomous, distinct but not apart. This development of its strong theoretical commitment has come through the cultivation of empirical investigations of a wide range of topics that are varied in their theoretical and analytical approaches but can nonetheless be traced back to a common trunk of strong-program theorizing and to its relationship to the great theoretical traditions of sociology. In that sense, the roots of the strong program, invisible to delinquent students who fail to read the source material, but even for those students vividly alive in their experience of the strong program as a way to think about culture and sociological analysis more generally, emerge from Jeff's earliest, most theoretically sweeping work. I don't think Jeff teaches Theoretical Logic in his classes; he didn't in any that I took at any rate. And yet, in some sense, it provides the animating spirit of the strong program, its "presuppositional assumption" (Alexander, I982: 89), that tightly integrates theory into all of its empirical endeavors and manifestations.

This webwork of thought and analysis cast between middle-range and general theory, though, is but one of the sources of the relative autonomy of the strong program, my topic in this essay. Another important source are Jeff's institutional innovations and achievements. Autonomy comes in part from being a program, but what is a program if not a colloquy? That observation has been literally true in the construction of the strong program in cultural sociology, and it wielded even greater influence on my experience as Jeff's student than the balancing act between theory and empiricism just described. The institutional side of the strong program, as I've heard it, starts with the Culture Club in the sociology department of UCLA. When Jeff moved to Yale he created, with Ron Eyerman and Phil Smith (and later Fred Wherry), the Center for Cultural Sociology (CCS). The CCS to my mind has been central to generating the relative autonomy of the strong program. The relative autonomy of an intellectual program, I would propose, involves two elements held in tension. One consists of that which sets it apart and allows it the freedom from other, perhaps more popular, powerful, or mainstream ways of thinking about a subject matter. This centripetal force is in tension, however, with a countervailing, cen- 
trifugal force that keeps it connected and relevant to the directions, trends, arguments, theoretical ebbs and flows of the - in this case - sociological discourse more generally. The CCS can be understood as an institutional answer to the challenge of keeping these forces in rough alignment, allowing neither for the full alignment of the strong program with other ways of thinking about and doing sociology, nor for it to spin off into some theoretical oubliette of its own devising.

The CCS managed this through a Friday workshop series that cultivated a deliberate mix of in-house presenters - graduate students, visiting scholars, and core faculty members - and invited guests (and simultaneously provided a framework around which a community of fellowship and inquiry could flourish). Some of the invited guests were fellow travelers, but plenty were not. The visiting scholars who spent more than a Friday at the CCS were themselves an intellectually diverse group, some more closely connected to the strong program, many less so, but all incorporated into the weekly scrum in ways that fostered the balancing act of relative autonomy. Through this weekly workshop the CCS directors fostered both of the countervailing forces necessary for constituting analytical autonomy, persistent themes and regular difference. And because the Friday meeting was a workshop, usually discussing papers and chapters that had not yet been published and which were frequently in an early state, this often led to robust debates over purpose, method and theory that provided rich opportunities to consider the confluence of strong program approaches with those of other cultural sociologists, as well as their divergence. The usual procedure was to circulate one or a few papers or chapters before the Friday workshop and then to have the presenter start off with a bare fiveminute statement about the work we had read, or how it came about, and then to launch into the discussion. Similarly, for the in-house presentations, the workshop format led to robust discussions about a wide range of theoretical formulations and approaches that helped to drive innovation and theoretical consolidation, as well as to provide a constant infusion of new methodological and theoretical thinking about the program, its direction, its possibilities, its contradictions, and its relationship to other ways of doing cultural sociology.

I loved the CCS workshop from the start, and knew it was the centerpiece of my graduate education. But I never wondered for a moment at its very existence and thus never spared a thought for the point that I want to make here: it was through the active and creative effort of Jeff and the other directors that this important institutional manifestation of the strong program's autonomy existed at all. Apart from any issues involving the autonomy of the program, it was during that workshop that I learned to do sociology and developed the habits of writing and thinking that I now rely on daily and that were the most valuable thing I learned as Jeff's student - the workshop taught it to me in ways an advisor never could. 
All of which is to say, it was only after leaving that I became better able to notice the intellectual and institutional architecture that made the sort of sociology I learned to do as a student in the Yale Center for Cultural Sociology possible. To talk about what it was like to be one of Jeff's students, at least for $\mathrm{me}$, is impossible without talking about this theoretical and institutional infrastructure that he and others assembled. It was a sphere for the production of a specific sort of sociological meaning centered around taking an often undervalued interpretive and theory-forward approach to the sociological analysis of the symbolic dimensions of human social life. It was also, though, a sphere of inquiry that was generous enough in its scope not to constrain and robust enough in its portfolio of theory, method and empirical application to sustain an ongoing engagement with a wide diversity of topics and ideas. The relative autonomy of this program seemed natural at first, and only later did I begin to appreciate what it took to build and maintain the qualities that made the CCS and the strong program such a distinctive and valuable sphere of inquiry: deep theoretical roots, and a constant effort to build, fund and let flourish an ongoing, focused, prolific communal discourse. What seemed at first unremarkable now represents to me with great clarity how much of what I learned as a graduate student I owe not just to who Jeff is and to all the support he gave me directly - debt enough - but also to the program, community and culture he has deftly built and tended.

Received on II/IO/20I8 | Approved on 6/2/2019

Matthew Norton received his PhD in Sociology from Yale University. He is Associate Professor in the Department of Sociology at the University of Oregon and is currently writing a book on piracy and state institutional development in the early modern English/ British empire. He has published articles on cultural sociology in the American Journal of Cultural Sociology, Sociological Theory, Eighteenth Century Studies, and the American Journal of Sociology. 


\section{BIBLIOGRAPHY}

Alexander, Jeffrey C. (20II). Fact-signs and cultural sociology: how meaning-making liberates the social imagination. Thesis Eleven, I04/I, p. 87-93.

Alexander, Jeffrey C. (I982). Theoretical logic in sociology, volume I: positivism, presupposition and current controversies. Berkeley: University of California Press.

Geertz, Clifford. (2000). Available light: anthropological reflections on philosophical topics. Princeton, N.J.: Princeton University Press.

Merton, Robert K. (I949). On sociological theories of the middle range. In: Social Theory and Social Structure. New York: Simon and Schuster, p. 39-53.

Weber, Max. (1958). From Max Weber: essays in Sociology. Edited by H. H. Gerth and C. W. Mills. New York: Oxford University Press. 


\section{A AUTONOMIA RELATIVA DE JEFFREY ALEXANDER}

Resumo

O programa forte em sociologia cultural ocupa um lugar específico na sociologia estadunidense contemporânea. Em um momento em que as teorias de médio alcance predominam, o programa forte, em certos aspectos, segue um modelo mais antigo de teorização por meio do desenvolvimento de um autoconsciente esforço teórico programático. Este artigo articula essa característica do programa forte com as suas relações com tradições teóricas anteriores que inspiram suas ambições (a despeito de suas consideráveis diferenças dessas tradições). Outro aspecto do programa forte que exerce uma importante influência é a sua identificação institucional com o Center for Cultural Sociology da Yale University. O artigo identifica nos encontros semanais do "culture workshop" promovidos nesse centro um nexo que lhe permite ao mesmo tempo perseguir o seu programa teórico específico e permanecer fortemente conectado aos desenvolvimentos mais gerais da sociologia cultural estadunidense.

\section{THE RELATIVE AUTONOMY OF JEFFREY ALEXANDER}

Abstract

The strong program in cultural sociology is distinctive in contemporary U.S. sociology. At a time when middlerange theory dominates, the strong program in some respects follow an older model of theorizing through the development of a self-consciously programmatic theoretical endeavor. The article traces this quality of the strong program to its relationship to older theoretical traditions that inspire its ambitions (though it differs from these in important ways). Another aspect of the strong program that exerts an important influence is its institutional identification with the Yale Center for Cultural Sociology. The article focuses on the Center's weekly culture workshop as a nexus that allows for it to both pursue a distinctive theoretical program that nonetheless remains closely connected to developments in U.S. cultural sociology more generally.
Palavras-chave

Sociologia cultural; programa forte; teoria de médio alcance; programas teóricos; instituições.

Keywords

Cultural sociology; strong program; middle-range theory; theoretical programs; institutions 